\title{
The Analysis on the Role of Dance Education in College Education
}

\author{
Min Zhu \\ Guangdong Dance and Drama College,Guangzhou ,China \\ chenyan@126.com
}

Keywords: Colleges and Universities; Dance education; Comprehensive development; Role; Analysis

\begin{abstract}
The Chinese nation has a long tradition of dance education. As an art education discipline, dance can harmoniously integrate different aspects of body, mind, emotions and society. Dance education in colleges and universities is a favorite course for college students. It can not only improve their body shape, cultivate their temperament, but also promote their all-round development. Therefore, dance education in colleges and universities is of great significance to every student and deserves constant promotion and encouragement so that it can develop rapidly. At present, compared with foreign countries, dance education in our country's universities is still in the primary stage, which also determines that there is still a lot of room for efforts in our country's universities. Therefore, continuously improving the quality of education and the quality of dancers is a relatively important educational issue at present.
\end{abstract}

\section{Introduction}

Chinese National Education includes morality, intelligence, body, beauty, and labor. Dance education is one of the important contents of aesthetic education. Its value and importance are no less than that of formal courses such as numbers, reason, and chemistry. It can not only encourage learners to increase their imagination and creativity, and thus better develop their potential, but also complement the formal courses. Make students develop autonomous habits and a sense of cooperation. Due to the characteristics of sports and aesthetic education, sports and aesthetic education can not only strengthen students 'bodies, cultivate students' sentiments, promote the harmonious development of students 'bodies and minds, but also enhance patriotism and collectivism. Cultivating tough will quality, healthy psychological quality, good collaborative spirit, stimulating and strengthening students 'creative rhythm, cultivating and developing students' aesthetic ability, imagination and innovative spirit have unique roles that can not be replaced. In today's competitive world, these qualities undoubtedly play an increasingly important role.

\section{Excellent dance education tradition}

First of all, the Chinese nation has a long tradition of dance education as far as the cultural and artistic heritage is concerned. The records of dance education in ancient Chinese times have been repeatedly seen in historical records. When the "Historical Records of the Five Emperors" was spoken and spoken, "the poetry was used as a standard to teach music .... the poetry, the song was long, the body was eternal, the law was harmony, and the eight sounds could be harmonious. : In the stone stone, the beasts dance. "This record is confirmed in the" Year of the Bamboo Book. " "The Year of the Bamboo Book" contains "The first use of 10,000 in the spring and February of the 17th year", which is far away from the era of Yu. It has already implemented 10,000 dance education for noble children in official schools. Wan dance is a kind of court dance with dry feathers as a dance instrument. Therefore, at least in the era of Shun, our country has implemented music and dance education in schools. By the beginning of the week, dance education had become customized and was a big idea. At that time, for schoolchildren of different ages, there were clear teaching requirements in terms of teaching content: "Ten years, learning music, singing songs, and dancing spoons. "" Adult Dance Elephant "("Book of Rites") and according to the norms of Zhou $\mathrm{Li}$, at different stages of time, there are corresponding regulations on the content of dance teaching: "When it is necessary to 
learn, learn to learn in spring and summer, and learn in autumn and winter." All are orderly. "(Preface to" Tongdian Volume 53 ") is the school run by the Zhou Dynasty government.

\section{Analysis of Dance Education in Colleges and Universities}

At present, dance education in colleges and universities is basically divided into two situations:

Dance Curriculum Arrangements in the Education System.This kind of situation is the common phenomenon of dance education in colleges and universities in China. It is a kind of dance education that belongs to the sports discipline under the arrangement of the education system and focuses on aerobics. Therefore, we must note that dance education in this case is at the initial stage of the entire dance education system.

Dance Specialization Courses under the Arts.In contrast to the preliminary stage of dance, this dance specialization class is designed for art students. It is mainly based on dance teaching, supplemented by other cultural disciplines. At the same time, it is worth noting that under the training of specialized classes, students 'dance performance will increase rapidly in a straight line. It is recommended that parents, if their children have enthusiasm and desire for dance, they can send their children to such classes, so that schools and teachers can train well, so that children can realize their dreams!

\section{Analysis of the Present Situation of International Dance Education}

We can see that in the current world education system, dance education can be roughly divided into two models: one is the universal education system represented by the United States; One is the early professional dance education system represented by the Soviet Union. In the United States, since the last century, there have been compulsory dance courses for students in elementary schools, middle schools, and universities, and the teaching goals are clear and self-contained. In 1994, the "Education Law of 2000" promulgated by the United States stipulated for the first time the "National Standards for Art Education" in the name of the government, and included music, dance, drama, fine arts, and film and television as art subjects. It has become one of the core disciplines of school education with various disciplines such as language and mathematics. It is worth noting that the various courses of the art department extend from the beginning of elementary school to the 12th grade, which is equivalent to high school graduation in China. "From elementary school to junior high school, music and dance are compulsory courses. Art courses take up slightly different hours each week. In the schools we see, there are fewer three school hours and more five school hours. "(Guomingda:" World Art Education ", P. 23) And almost all universities in the United States have dance disciplines. In the United States 'general education and even higher education system, dance is not only regarded as an art form, but also as an important educational means to cultivate, educate, beautify, and optimize people. It has its independent and irreplaceable status as an educational discipline. There is no doubt that this kind of universal dance education mechanism is of great benefit to the educatees in improving their physical and mental health, moral and cultural qualities, and artistic literacy, as well as in improving the civilized personality of the educatees in an all-round way. Dance education represented by the Soviet Union in the past emphasized and committed to the training of professional dance talents. Some scholars call it the early professional dance education model. This model is characterized by the formation of a relatively independent and closed dance education subsystem in the entire national education system. The advantage of this mechanism is that it can maximize the discovery and strengthening of a group of outstanding dance professionals. This kind of dance education is mainly implemented through secondary professional education.

\section{The Relationship between Dance Education and Human Development in Colleges and Universities}

Aesthetic Education Function of Dance.As a category of art education, the aesthetic education function of dance education is obvious to all. In the dance education of vocational schools, dance 
aesthetic education helps students to carry out fitness and bodybuilding exercises, helps students find themselves and self-feeling, improves self-awareness and aesthetic ability, and cultivates good personality qualities and noble sentiments. Dance education can also improve students 'appreciation of beauty. Whether it is natural beauty or artistic beauty, people need to have a certain degree of aesthetic knowledge to be able to perceive and appreciate them well, so as to strengthen their own excavation and discovery of China and the United States in social life. Like the teaching of knowledge and skills, the cultivation and improvement of aesthetic ability is also an important part of the overall development of human beings, and it is also an important expression of the social significance of dance education. The characteristic of dance education is artistic beauty. The aesthetic experience can help people form a healthy and good civilized life style. Dance education can also enlighten the educatees to carry on the deep aesthetic perception, so that it forms a kind of beautiful character and noble soul. In addition, dance art can also improve students 'adaptability, enhance interpersonal communication, and increase people's social integration and sociality. This will make vocational school students more adaptable in the future.

The Moral Function of Dance.The moral education function of dance education includes personality education and emotion education. In vocational schools, dance education plays an important role in the formation and cultivation of students 'individual psychological characteristics and moral character. Dance can promote the formation and development of personality's attitude characteristics, will characteristics, emotional characteristics, and rational characteristics: personality characteristics such as honesty, self-confidence, positivity, self-control, autonomy, independence, tenacity, seriousness, responsibility, enthusiasm, and daring.

Dance can cultivate students 'noble sentiments, especially some healthy and upward dance programs, all have rich ideological education content that conforms to students' ideological and psychological characteristics. Dance education is a kind of educational activity that integrates teaching, training, rehearsal and performance. It helps to cultivate students 'strict concept of discipline and helps to cultivate a sense of unity, cooperation and cooperation. Therefore, through this form of education, students can have a team spirit and love spirit. In addition, dance training can also train a person's will and develop the ability to overcome difficulties, such as the following legs, lower waist, turn over, jump and so on. Some skillful movements and basic skills training are not the work of a day and require a long process, and it is difficult to complete without certain perseverance, and the cultivation of such perseverance lays a certain foundation for the road to success in the future. To hone their strong will.

The Intellectual Function of Dance. Two important building blocks in the process of human civilization are science and art, and the highest goal of the comprehensive development of human beings is to achieve a balanced transcendence of science and art. In the practice of dance education, it can promote the balanced development of people's left and right brains, and it can better promote people's imagination and association ability and creative development ability. In both artistic creation and scientific invention, imagination and creativity are indispensable. Any kind of creation or invention starts with an imagination. Imagination is far more important than knowledge, for imagination represents an inexhaustible source of creation. In 1994, the United States formulated the "National Standards for Dance Art Education" and put forward specific skills and knowledge requirements for students 'dance education. Dance education can promote the cultivation of people's creative thinking, which contains artistic beauty, natural beauty and cultural beauty can help people to establish a spirit of pioneering, enterprising and innovative. In addition, while training people to form a good ability to solve problems, dance education can also enable people's emotional will, image thinking, creativity, etc. to be fully developed, thus having an important impact on the future development of people.

Sports Functions of Dance.The ontological value of dance has the function of strengthening physical fitness. It can enhance physical fitness and promote health. As students need to carry out physical training for physical fitness, such as strength, flexibility, control, stability, coordination of various parts of the body, flexibility, and endurance, to create a perfect body shape, the teaching and training of dance can promote students 'all-round development. Strengthen students 'physical fit- 
ness. Students are in a critical period of long body growth. In the process of dance learning and training, all aspects of the body and strength, speed, endurance, etc. have been exercised. This kind of exercise has great benefits for promoting the healthy development of students 'bodies.

\section{Vocational College Dance Education should Pay Attention to the Problem Analysis}

Professionalism in dance teaching. The specialty of dance teaching directly affects the performance and level of Chinese dance students. Many schools have not done much to hire dance teachers. Therefore, many dance teachers themselves are not professional. Naturally, they can not create a professional dance atmosphere for students, and their own dance skills are difficult to improve.

Understanding and communication between teachers and students. As a dance teaching, it is different from cultural education. Although both are education, it is worth noting that there is a huge difference between the two. Because there is physical contact between the dance teacher and the student, the dance teacher's gender will also affect the school's dance teaching curriculum. It is also a problem that colleges and universities should pay attention to to to properly match the gender of teachers. In addition, there is also a key issue is that the communication between teachers and students should be highly valued. Dance teachers have more contact time with students than cultural teachers, and exchanges are more frequent. Therefore, it is more worthwhile for universities to gradually advance and strengthen reasonable improvements.

\section{Conclusion}

Dance education in colleges and universities is a very good way for dance students to learn dance. I hope that students can also actively cooperate with your teachers and study dance hard. Through their own efforts and struggle to realize their own dance dream! In the process of learning dance, we must constantly enhance our personal charm, integrate ourselves into the world of dance, and continuously cultivate tough personality and good personality. In order to promote their own all-round development, in the life of the road can walk more exciting! The teacher is the bridge between students and dance. A good dance teacher is a very precious treasure for students. A good dance student will also bring warmth and touch to the teacher. To sum up, the development of dance education is closely related to the development of students. The science and education department should also continuously improve the teaching staff and professional level of dance education in colleges and universities in order to achieve the leap-forward development of dance education in China.

\section{References}

[1] You JiaYing. The investigation and research of higher dance education[D]. China Academy of Art, 2007.

[2] J Niu.Thinking about the Present Situation and the Future Development Trend of Higher Vocational Teaching Materials[J].Journal of Beijing Vocational College of Finance \& Commerce, 2014.

[3] R Wang.Research on the Current Situation and Development Trend of College English Teaching Assessment System in China[J].International Conference on Mechatronics,2017.

[4] B Hu.On New Models of Music-dance Education in Colleges and Universities[J].Journal of Beijing Dance Academy , 2011.

[5] YF Su.How to enhance the effectiveness of dance education in colleges and universities[J].Journal of Jiamusi Vocational Institute , 2016.

[6] HR Zhou .The Present Situation and Development Trend of Physical Education in Higher Vocational Colleges[J].Journal of Liaoning Higher Vocational,2017.

[7] P Zeng, D Wang.Discussion on the Current Situation and Reform Trend of Fundamental Chemistry Teaching in Pharmaceutical Higher Vocational College[J].Experiment Science \& Technology,2015. 
[8] JJ Zhang.The Analysis on the Problems and the Countermeasures in Higher Vocational Dance Education[J].Journal of Jincheng Institute of Technology , 2018. 